\title{
Glycemic Index: Effect of Food Storage under Low Temperature
}

\author{
Marina Cassab Carreira, Franco Maria Lajolo and Elizabete Wenzel de Menezes* \\ Universidade de São Paulo; Faculdade de Ciências Farmacêuticas; Departamento de Alimentos e Nutrição \\ Experimental; Av.Prof. Lineu Prestes, 580, Bloco 14; 05508-900; wenzelde@usp.br; São Paulo - SP - Brazil
}

\begin{abstract}
This study was carried out to evaluate the influence of food storage under low temperature $\left(-20^{\circ} \mathrm{C}\right)$ and the resistant starch formation, both on the glycemic index (GI). The GI of only cooked and cooked and stored foods under $-20^{\circ} \mathrm{C}$ for 30 days was evaluated in short-term tests with humans. Significant increase on the RS content was evidenced for all the stored foods. The food storage resulted in a significant decrease on the GI of beans and chickpeas; the GI of pasta remained the same and the GI of corn meal increased. Thus, the RS formation showed reduced influence on the glycemic index. The storage of starchy foods under low temperature can collaborate to the RS intake but its effect on the GI will depend on the characteristics of the carbohydrates of eac $h$ food.
\end{abstract}

Key words: Starch, glycemic index, resistant starch, storage

\section{INTRODUCTION}

Carbohydrates have an essential physiological role in the body. The rate of digestion and absorption of carbohydrates can be determinant for the metabolic control of some human chronic noninfectious diseases (FAO/WHO, 1998; Jenkins et al., 2002). For this reason, there has been a growing interest in the biological utilization of carbohydrates by the human body, especially referring to starch and dietary fiber and their effects on the glycemic response and on the large bowel physiology (FAO/WHO, 1998; Danone Vitapole/ FAO, 2001; Lajolo et al., 2001; Jenkins et al., 2002).

The glycemic index (GI), which quantifies the glycemic response produced by foods, evaluates indirectly the in vivo availability of the carbohydrates (FAO/WHO, 1998; Wolever et al., 1991). Currently, the importance of the GI studies is linked to the possible therapeutical and physiological effects of diets with low GI on healthy, obese, diabetic and hyperlipidemic subjects. The GI has also been related to colon diseases and physical activity (FAO/WHO, 1998; Danone Vitapole/ FAO, 2001; Jenkins et al., 2002). In spite of the evidenced positive physiological effects of the low GI foods, there is little information available about the GI of Brazilian foods (Menezes et al., 1996).

The extension and duration of the blood glucose rise after a meal depends on the rate of absorption, which depends on certain factors such as gastric emptying as well as the rate of hydrolysis and diffusion of hydrolysis products in the small intestine. Several factors can interfere in the rate of in vivo hydrolysis and absorption of starch (FAO/WHO, 1998). Starchy foods cooked with a proper amount of water suffer gelatinization. While the food is cooling, retrogradation takes

\footnotetext{
* Author for correspondence
} 
place making starch less and less available for digestion. High content of amylose, low moisture of starch gel, low temperature of storage and the presence of other components in foods may also be related to the starch retrogradation (Fredriksson et al., 1998; Thompson, 2000). This retrograded starch represents a significant source of resistant starch. At the same time, the usual domestic cooking followed by cooling or freezing leads to resistant starch formation in certain kinds of starchy foods (Thompson, 2000; Menezes and Lajolo, 2000; Haralampu, 2000; Rosin et al., 2002; Tovar et al., 2002).

The main objective of this study was to evaluate the influence of food storage under low temperature $\left(-20^{\circ} \mathrm{C} / 30\right.$ days $)$ and the resistant starch formation, both on the GI.

\section{MATERIALS AND METHODS}

\section{Samples}

Five starchy foods usually consumed by the Brazilian population were tested: white bread from local market, dried beans from Broto Legal Com. Imp. Exp. Ltda, white spaghetti from Quaker Brasil Ltda, dried chick-peas from Hikari Ind. Com. Ltda and corn meal from Hikari Ind. Com. Ltda.

\section{Food preparation and storage}

White bread was used as standard food, without being processed before its consumption. The other foods were submitted to two kinds of processing: cooking, or cooking and storage under $-20^{\circ} \mathrm{C}$ for 30 days. Beans and chick-peas were soaked in water at $4^{\circ} \mathrm{C}$ for 12 hours and then submitted to cooking without pressure during 36 and $70 \mathrm{~min}$, respectively. The corn meal and white spaghetti were cooked for 90 and $20 \mathrm{~min}$, respectively. No seasoning or ingredients were added to any food. After cooking, the water was thrown out and the foods were weighed and packed separately. Half of the portions was consumed on the same day of cooking and the other half was stored under $20^{\circ} \mathrm{C} / 30$ days. Each portion of food had exactly $50 \mathrm{~g}$ of total starch. Only the foods that were stored under $-20^{\circ} \mathrm{C} / 30$ days were heated once more before consumption (microwave oven during 3-5 $\mathrm{min})$.

\section{Chemical methods}

In order to determine total starch and resistant starch contents, standard analytical methods were used (Goñi et al. 1996; 1997). The detailed results from chemical analyses were already published (Rosin et al., 2002).

\section{Assays with humans}

Ten healthy volunteers, one man and nine women, at the age of $33.2 \pm 7.9$ years, who had normal body mass indices $\left(22.8 \pm 2.1 \mathrm{~kg} / \mathrm{m}^{2}\right)$ participated in the study. The Ethical Research Committee of the School of Pharmaceutical Science, Sao Paulo University, approved the experimental protocol and the volunteers gave their written consent. The volunteers came to the laboratory once a week after a 10-hour fast. White bread (standard food) was tested twice in the first two weeks. In the following four weeks, the volunteers consumed foods only cooked and in the four last weeks they consumed foods which were cooked and stored under $-20^{\circ} \mathrm{C}$ for 30 days. The volunteers consumed a different kind of food in each week with $150 \mathrm{ml}$ of water. The blood glucose was determined from each subject on fast (time zero) and, afterwards, a food was consumed. The volunteers had ten min to consume each portion. Blood samples were taken at 15, 30, 45, 60, 90 and $120 \mathrm{~min}$ after food ingestion in order to elaborate the glycemic curve (Wolever et al., 1991). The glucose was measured in capillary whole blood with blood glucose sensors (Precision Q-I-D ${ }^{\mathrm{TM}}$ MediSense $^{\circledR}$ ).

\section{Glycemic index (GI) calculation}

The incremental area under the glycemic response was geometrically calculated, using the trapezoidal rule and the area under the fast line was ignored (Wolever et al., 1991; FAO/WHO, 1998). The GI of each studied food was calculated from the resulting area and the white bread area was considered as the standard (100\%) (FAO/WHO, 1998).

\section{Statistical analysis}

The GI was expressed as mean \pm SEM and the other results as mean $\pm \mathrm{SD}$. Comparisons of the mean values were performed by student $t$ test using Minitab-Windows computer system, version $10.1,1994$. Linear regression analysis and $\mathrm{p}-$ value for correlations were estimated using the Minitab-Windows. 


\section{RESULTS}

Table 1 shows the area under the glycemic curve and the GI after the ingestion of foods under two kinds of processing (A-cooked and B-cooked and stored under $-20^{\circ} \mathrm{C} / 30$ days) and RS content of the samples. Legumes (beans and chick-peas) produced the lowest areas under the glycemic curve for both kinds of food processing. The spaghetti submitted to the same kinds of processing produced similar glycemic areas. The corn meal, cooked and stored under $-20^{\circ} \mathrm{C} / 30$ days, produced a glycemic area higher than the one produced by the cooked corn meal that was consumed immediately after it was cooked, (Fig.1).

Table 1 - Area under the glycemic curve and glycemic index (GI) after the ingestion of foods under two kinds of processing and resistant starch (RS) content

\begin{tabular}{l|c|c|c|c}
\hline Food & $\begin{array}{c}\text { Food } \\
\text { processing }\end{array}$ & $\begin{array}{c}\text { Area under the glycemic } \\
\text { curve (mmolxmin/L) }\end{array}$ & $\begin{array}{c}\text { GI } \\
(\mathbf{\%})\end{array}$ & $\begin{array}{c}\text { RS } \\
(\boldsymbol{\%} \text { dry wt) }\end{array}$ \\
\hline White Bread & & $207 \pm 17$ & 100 & \\
Corn Meal & A & $152 \pm 17^{\mathrm{a}}$ & $74 \pm 8^{\mathrm{a}}$ & $4.20 \pm 0.18^{\mathrm{a}}$ \\
& B & $199 \pm 15^{\mathrm{b}}$ & $96 \pm 7^{\mathrm{b}}$ & $4.86 \pm 0.45^{\mathrm{b}}$ \\
White Spaghetti & A & $133 \pm 15^{\mathrm{a}}$ & $64 \pm 7^{\mathrm{a}}$ & $1.38 \pm 0.00^{\mathrm{a}}$ \\
& $\mathrm{B}$ & $129 \pm 11^{\mathrm{a}}$ & $62 \pm 5^{\mathrm{a}}$ & $2.22 \pm 0.14^{\mathrm{b}}$ \\
Beans & $\mathrm{A}$ & $79 \pm 8^{\mathrm{a}}$ & $38 \pm 4^{\mathrm{a}}$ & $4.75 \pm 0.30^{\mathrm{a}}$ \\
& $\mathrm{B}$ & $38 \pm 3^{\mathrm{b}}$ & $18 \pm 2^{\mathrm{b}}$ & $6.99 \pm 0.34^{\mathrm{b}}$ \\
Chick - peas & $\mathrm{A}$ & $70 \pm 8^{\mathrm{a}}$ & $34 \pm 4^{\mathrm{a}}$ & $5.86 \pm 0.24^{\mathrm{a}}$ \\
& $\mathrm{B}$ & $46 \pm 3^{\mathrm{b}}$ & $22 \pm 2^{\mathrm{b}}$ & $6.35 \pm 0.36^{\mathrm{b}}$ \\
\hline
\end{tabular}

$\mathrm{A}=$ cooked; $\mathrm{B}=$ cooked $/$ stored $\left(-20^{\circ} \mathrm{C} / 30\right.$ days $)$

GI - mean \pm SEM; White bread $=100 \%$ (standard $)$

$\mathrm{RS}$ - mean $\pm \mathrm{SD}$

Different letters between treatments show significant difference $(\mathrm{p}<0.05)$.

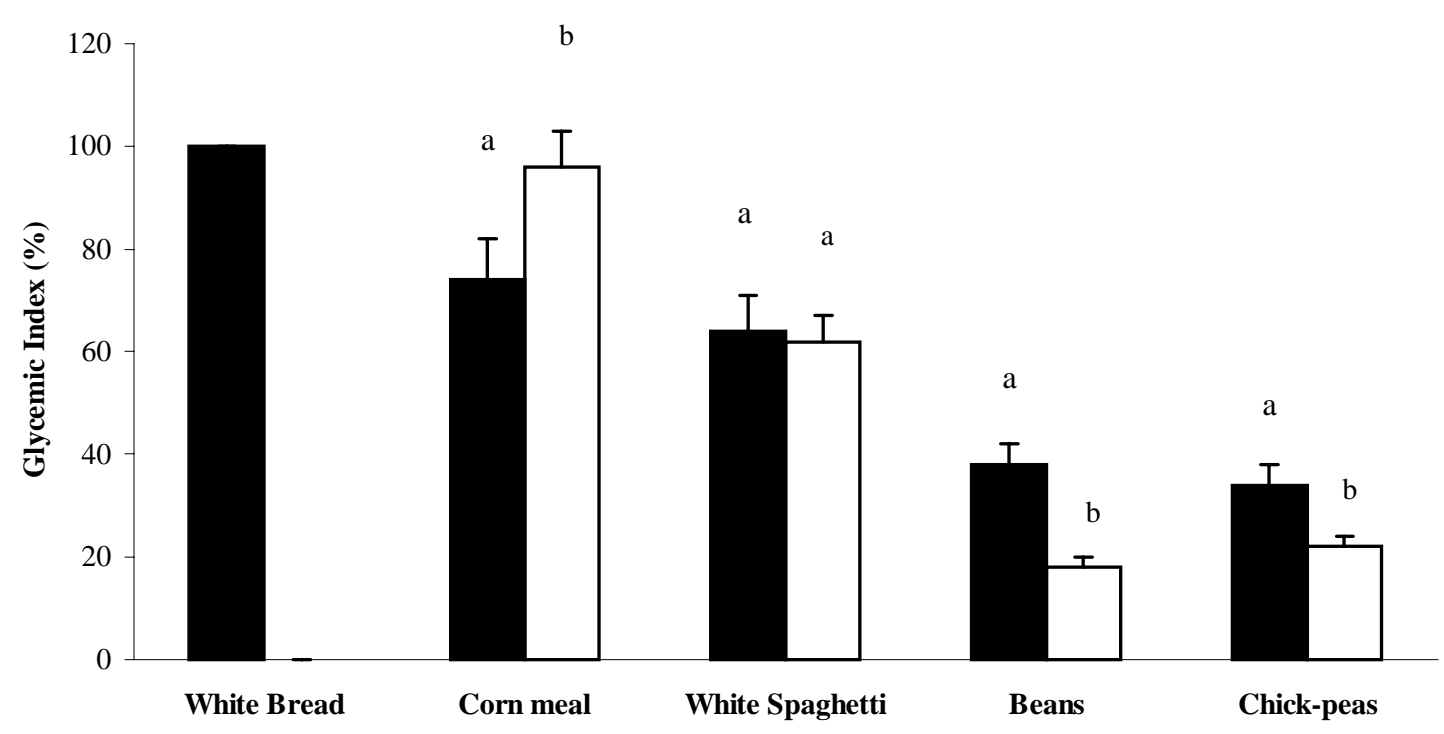

cooked $\square$ cooked and stored (-20 $\mathrm{C} / 30$ days $)$

Figure 1 - Glycemic index of foods under two kinds of processing (mean \pm SEM). Values with different letters are significantly different, $\mathrm{p}<0.05$. 
The storage under $-20^{\circ} \mathrm{C} / 30$ days led to the resistant starch formation. Each food had the following increases: $61 \%$ for white spaghetti, $47 \%$ for beans, $16 \%$ for corn meal and $8 \%$ for chickpeas. The RS formation was calculated from the RS content of cooked food, considering it as $100 \%$.

\section{DISCUSSION}

Starch is potentially digested by the amylolitic enzymes secreted by the human's digestive tract, but some factors can interfere in the rate at which the starch is in vivo hydrolyzed and absorbed and one of these factors is the kind of process which the food has gone through (Björck, 1996; FAO/WHO, 1998). The low glycemic responses produced by the only cooked legumes (beans and chick-peas) were similar to the ones found in the literature (Menezes et al., 1996; FAO/WHO, 1998). Those GI were, significantly, even more reduced after the foods storage under $-20^{\circ} \mathrm{C} / 30$ days. At the same time, it was possible to notice an increase in the RS content, by the formation of type III RS (retrograded amylose/amylopectin). Other researchers who studied legumes and other kinds of foods also noticed the RS formation when the food was stored under low temperatures (Bravo et al., 1998; Menezes and Lajolo, 2000; Tovar et al., 2002).

When the food is cooling, the starch retrogradation and the RS formation are activated and even less starch is available for digestion (Fredriksson et al., 1998; Thompson, 2000). In the case of the studied legumes, this procedure interfered in the glycemic response, resulting in interesting sources of low GI and high content of RS foods. Foods such as corn meal and spaghetti are made out of grains that have their structures broken to elaborate the meal. This processing disrupts the cellular wall making the starch more available. It can explain, in part, the high GI produced by the corn meal when it is consumed immediately after it was cooked (Björck, 1996).

A significant increase on the GI of the stored corn meal under $-20^{\circ} \mathrm{C} / 30$ days was observed. It was expected that the RS formation (16\%), verified under these conditions, was an important factor for the GI reduction. However, the opposite happened. This effect can be attributed to the presence of non gelatinized starch even after cooking and storage.
When corn meal was thawed and reheated, more starch was made available for digestion and absorption.

The hypothesis which quoted that the more processed the food the higher GI it produced (Brand et al., 1985) contrasted with the study of pasta, which showed that the GI was reduced by processing (Jenkins et al., 1983). The wheat starch might have a different performance from that of rice, corn and potato in response to cooking and processing, maybe gelatinizing differently from other starches (Williams and Bowler, 1982). Since there are several kinds of pasta, in different shapes, several protein contents and ways of processing, different metabolic effects can come out. Pasta is a usual starchy food and, in the form of spaghetti, has a low GI (nearly $60 \%$ ) (Wolever et al., 1986). Studies which aim to evaluate the effect of low GI diets (breakfast) on the glucose tolerance in the subsequent meal (lunch), use the spaghetti as a low GI food (Liljeberg and Björck, 2000).

In the current study, a GI of $64 \%$ was observed in cooked white spaghetti and a GI of $62 \%$ was observed in the spaghetti which was stored after been cooked. A significant increase of the RS content in the stored sample (61\%) was observed. However, just like in the corn meal, this RS formed did not interfere in the GI. From the linear regression analysis, a reduced but significant negative correlation between the GI and RS starch content of the studied foods was observed $(y=-$ $9.68 \mathrm{x}+96.9 ; \quad \mathrm{r}=0.715 ; \quad \mathrm{p} \leq 0.032 ; \mathrm{n}=9$ ). Consequently, these results suggested that the resistant starch had little influence on the GI. On the other hand, other factors besides the resistant starch content seemed to be involved in the differentiated GI of foods.

The relation between the resistant starch content and the GI of foods is not simple to be established. One could presume that foods with high RS content produce low GI. Nevertheless, this is not a rule. Although they show high resistant starch amounts, some foods produce high GI, for example baked potatoes and corn flakes. However, barley and legumes produce a low GI associated to a high RS percentage (Truswell, 1992).

The use of the GI as a tool to elaborate a food planning, aiming the prevention and control of chronic non-infectious diseases, has been used and recommended in several countries (Brand-Miller et al., 1997; FAO/WHO, 1998; Frost and Dornhorst, 2000; Danone Vitapole/ FAO, 2001). 
In order to make this practice easier, it is important to make all the efforts to expand the alternatives of low GI foods and products.

The RS has been identified as the main substrate for the bacterial fermentation and it seems to play a role in the human body similar to the one of the dietary fiber (Björck, 1996; Haralampu, 2000; Lajolo et al., 2001). The consumption of foods that are sources of dietary fiber and RS has been encouraged in order to prevent and control chronic non-infectious diseases (Björck, 1996; FAO/WHO, 1998). At the same time, the current RS intake in Latin America and in Brazil is reduced, oscillating between 3-4g/day (Lajolo and Menezes, 2001; Lajolo et al., 2001). The $-20^{\circ} \mathrm{C} / 30$ days storage induced RS formation for all the studied foods. The increase of RS content varied from $8 \%$ to $61 \%$. It is important to notice that this kind of food storage is a usual household procedure and it can contribute to increase both the RS content and intake.

In conclusion, the storage of starchy foods under $20^{\circ} \mathrm{C}$ for 30 days can represent a way of increasing the RS intake. The GI might, or not, be affected by the storage under low temperature, depending on the characteristics of the carbohydrates of each food.

\section{ACKNOWLEDGMENTS}

The authors acknowledge with gratitude the financial support granted by the "Fundação Coordenação de Aperfeiçoamento de Pessoal de Nível Superior" (CAPES), "Conselho Nacional de Desenvolvimento Científico e Tecnológico" (CNPq), PRONUT-Post Graduation Course FCF/FEA/FSP-USP, and the dedication and collaboration of the volunteers of the study.

\section{RESUMO}

O estudo foi realizado para avaliar a influência do armazenamento de alimentos sob baixa temperatura e a formação de amido resistente sobre o índice glicêmico (IG). O IG de alimentos cozidos ou cozidos e armazenados a $-20^{\circ} \mathrm{C}$ por 30 dias foi avaliado em ensaios de curta duração com humanos. Aumento significativo no conteúdo de AR foi evidenciado para todos os alimentos armazenados. $\mathrm{O}$ armazenamento dos alimentos resultou em significativa redução no IG do feijão e do grão de bico. O IG do macarrão foi o mesmo e da polenta sofreu aumento. Desta forma, a evidenciada formação de AR mostrou reduzida influência no IG. O armazenamento de alimentos fonte de amido sob baixa temperatura pode colaborar com a ingestão de AR, mas o efeito sobre o IG vai depender das características dos carboidratos de cada alimento.

\section{REFERENCES}

Björck, I. (1996), Starch: nutritional aspects. In: Eliasson, A. C. (ed.). Carbohydrates in food. New York : Marcel Dekker Inc. pp. 505-553.

Brand, J. C.; Nicholson, P. L.; Thorburn, A. W. and Truswell, A. S. (1985), Food processing and the glycemic index. Am. J. Clin. Nutr., 42, 1192-1196.

Brand-Miller, J.; Colagiuri, S. and Foster-Powell, K. (1997), The glycemic index is easy and works in practice. Diabetes Care, 20, 1628-1629.

Bravo, L.; Siddhuraju, P. and Saura-Calixto, F. (1998), Effect of various processing methods on the in vitro starch digestibility and resistant starch content of Indian pulses. J. Agric. Food Chem., 46, 4667-4674.

Danone Vitapole/FAO (2001), Glycaemic Index and Health: the Quality of the Evidence. Danone Vitapole/ FAO, Nutrition and Health Collections. France : Éditions John Libbey Eurotext. 48 pp.

Food and Agricultural Organization/ World Health Organization (FAO/WHO) (1998), Carbohydrates in Human Nutrition: Report of a Joint FAO/WHO Expert Consultation, April 14-18, 1997; Food and nutrition paper. Rome : FAO. 140 pp.

Fredriksson, H.; Silverio, J.; Andersson, R.; Eliasson, A. C. and Aman, P. (1998), The influence of amylose and amylopectin characteritics on gelatinization and retrogradation properties of starches. Carbohydr. Polym., 35, 119-134.

Frost, G. and Dornhorst, A. (2000), The relevance of the glycaemic index to our understanding of dietary carbohydrates. Diabet. Med., 17, 336-345.

Goñi, I.; Garcia-Alonso, A. and Saura-Calixto, F. (1997), A starch hydrolysis procedure to estimate glycemic index. Nutr. Res., 17, 427-437.

Goñi, I.; García-Diz, L.; Mañas, E. and Saura-Calixto, F. (1996), Analysis of resistant starch: a method for foods and food products. Food Chem., 56, 445-449.

Haralampu, S. G. (2000), Resistant starch - a review of the physical properties and biological impact of $\mathrm{RS}_{3}$. Carbohyd. Polym., 41, 285-292.

Jenkins, D. J. A.; Wolever, T. M. S.; Jenkins, A. L.; Lee, R.; Wong, G. S. and Josse, R. (1983), Glycemic response to wheat products. Reduced response to pasta but no effect of fiber. Diabetes Care, 6, 155-159. 
Jenkins, D. J.; Kendall, C. W.; Augustin, L. S.; Franceschi, S.; Hamidi, M.; Marchie, A.; Jenkins, A. L. and Axelsen, M. (2002), Glycemic index: overview of implications in health and disease. Am. $J$. Clin. Nutr., 76, 266S-273S.

Lajolo, F. M. and Menezes, E. W . (2001), Dietary fiber and resistant starch intake in Brazil: recommendations and actual consumption patterns. In: Cho, S. S. and Dreher, M. L. (ed.). Handbook of dietary fiber. New York : Marcel Dekker. pp. 845-858.

Lajolo, F. M.; Saura-Calixto, F.; Wittig de Penna, E. and Menezes, E. W. (2001), Fibra dietética en Iberoamérica: Tecnología y salud. Obtención, caracterización, efecto fisiológico y aplicación en alimentos. CYTED /CNPq. São Paulo : Varela. 469 pp.

Liljeberg, H. and Björck, I. (2000), Effects of a low glycaemic index spaghetti meal on glucose tolerance and lipaemia at a subsequent meal in healthy subjects. Eur. J. Clin. Nutr., 54, 24-28.

Menezes, E. W. and Lajolo, F. M. (2000), Contenido de fibra dietética y almidón resistente en alimentos $y$ productos iberoamericanos. Proyecto CYTED XI.6 Obtención y caracterización de fibra dietetica para su aplicación em alimentos para regímenes especiales, CYTED/CNPq. São Paulo : Docuprint. 121 pp. (http://www.fcf.usp.br/cytedxi6).

Menezes, E. W.; Lajolo, F. M.; Seravalli, E. A. G.; Vannucchi, H. and Moreira, E. A. M. (1996), Starch availability in Brazilian foods. In vivo and in vitro assays, Nutr. Res., 16, 1425-1436.

Rosin, P. M.; Lajolo, F. M. and Menezes, E. W. (2002), Measurement and characterization of dietary starches. J. Food Compos. Anal., 15, 367-377.

Thompson, D. B. (2000), Strategies for the manufacture of resistant starch. Trends Food Sci. Technol., 11, 245-253.

Tovar, J.; Melito, C.; Herrera, E.; Rascón, A. and Pérez, E. (2002), Resistant starch formation does not parallel syneresis tendency in different starch gels. Food Chem., 76, 455-459.

Truswell, A. S. (1992), Glycaemic index of foods. Eur. J. Clin. Nutr., 46, 91S-101S.
Williams, M. R. and Bowler, P. (1982), Starch gelatinization: a morphological study of Triticcae and other starches. Starch/Staerke, 34, 221-223.

Wolever, T. M.; Jenkins, D. J. A.; Jenkins, A. L. and Josse, R. G. (1991), The glycemic index: methodology and clinical implications. Am. J. Clin. Nutr., 54, 846-854.

Wolever, T. M.; Jenkins, D. J. A.; Kalmusky, J.; Giordano, C.; Giudici, S.; Jenkins, A. L.; Thompson, L. U.; Wong, G. S. and Josse, R. G. (1986), Glycemic response to pasta: effect of surface area, degree of cooking and protein enrichment. Diabetes Care, 9, 401-404.
Received: May 15, 2003; Revised: September 30, 2003; Accepted: January 26, 2004. 